\title{
FEMALE CHARACTER'S STRUGGLE TO GET SYMBOLIC CAPITAL IN DAISY GOODWIN'S THE AMERICAN HEIRESS
}

\author{
Tiara Widyaiswara \\ tiarawidya@unisla.ac.id \\ Program Studi Pendidikan Bahasa Inggris, Universitas Islam Lamongan
}

\begin{abstract}
The female characters struggle in The American Heiress is very interesting to be analyzed because the story tells about the sacrifice love which containing of contestation desired multicultural identities. This study is aimed to analyze the struggles of female characters to get symbolic capital which focus on Cora Cash and Charlotte symbolic struggle to be the new Duchess. To support this study, the practice of theory by Pierre Bourdieu is used as a concept of the symbolic struggle which involved to the contestation each character. This study applies qualitative research study. The result of this study is Cora Cash and Charlotte are done the struggle, they have different amount of the capital which Cora is more accomplish all of the capitals than Charlotte. It can be seen by the movement of Cora's position is different before and after she goes to England. Her first coming to England she is the new comer, she tries to show her strategy until she gets the symbolic capital as the wife of the Duke.
\end{abstract}

Keywords: Contestation, capital, Pierre Bourdie

\section{INTRODUCTION}

Every human lives in a certain social place. In the field is a place to compete the capital to get the power, wealth, and position. To get it all, the agents fought and competed in practice of contestation. Due to the practice is needed of capital and habitus it can be same or more with other individuals in order to maintain or change the structure class, it is differenced to agent who do not have the capital.

Contestation not only happens in the people who have a high social class but also with the lower class who want to change their position. For the potentate or class domination they also want still prevails and maintains the status quo. Therefore they choose to do capital and of strategies used in the field.

This reality not only happen in a real life but also in a literary work because some expert said that a literary work is imagination or mirror of life, because in a literary work tells about the story of life. The example of literary works which may include as contestation is Daisy Goodwin a novel, entitle The American Heiress. This novel is the stunning New York Time bestseller in 2011, the story is set in two countries England and America, tells about the American heiress or millionaires who have everything in her life, marry to British aristocrats in return for title and social status to obey her mother ambitions. After marriage, she faces many of traps and betrayals of an old world's aristocracy.

The American Heiress has interesting things to be observed because the story tells about the sacrifice love which containing multicultural identities, the differences of traditions, customs, and values especially for their identity. Beside it, the novel tells about social class; the aristocrat, bluebloods and cultural class in England and America. The competition each character to take a position in society looked clearly. In the novel the main character, Cora Cash trying to adapt the different cultures to get happiness in her marriage, attracts attention to her husband. At the end of the story she get dilemma between left her husband to escape with her boyfriend's in the past who love her so much or save her 
household. Finally, she takes decision to stay with her husband in England.

Based on the short explanation above the novel The American Heiress is appropriate to analyze using The Forms of the Capital concept by Pierre Bourdieu, because the story contains of Capital where the struggles was done by the female's characters, not only use the Economic capital but also the others Capital to get the symbolic capital in a field. According to Bourdieu, the capital it can be defined more widely and include material things which has symbolic and significant in accordance cultural (Harker: 2009). The fundamental species Capital break down into; Social Capital, Cultural Capital, Economic Capital, and Symbolic Capital.

\section{METHOD}

This study applies qualitative research design as the characteristic of the study are in line with the characteristics of qualitative research from Bogdan and Biklen (1982: 30). There are three sub characteristics; it has natural setting, kind of descriptive text, and the key instrument is the writer self. It can be conclude that the data ca not be manipulated from the context, beside it the data are taken from the narrator's narration and the utterances of the characters. Source of data is a novel by Daisy Goodwin entitled The American Heiress. The analysis of the novel is by gathering the data, interpreting the data, and writing the conclusion.

\section{DISCUSSION}

\section{The Social Space of Cora Cash}

The social space is the position of agent and the others in a certain field. The social space in this novel will be classified into two social spaces, the social space of Cora Cash in America and the social space of Cora Cash in England. Firstly, the social space of Cora in Newport, America is represented by herself as the daughter of Cash family who has the high social status than the other social agent because they have the material possessions. While the social space of Cora Cash in England is represented by another agent who lives in aristocrat family. In this social space shows the position of Cora and the other character as the social agent in aristocrat family

\section{The Social Space of Cora Cash in America}

In America, the family of Cora Cash is one of the American millionaires in the 19th century, come into being Cash family. The members of the family are Mrs. Cash (mother), Mr. Winthrop (father), and Berta (the professional maid). The novel told that as the child and the only daughter Cora always obeys what her mother command. Her position is dominated by her parent, for everything what she wants is depending on them. Even though, she never concerned about it. By her attitude, Cora gets her image in society as the perfect princess.

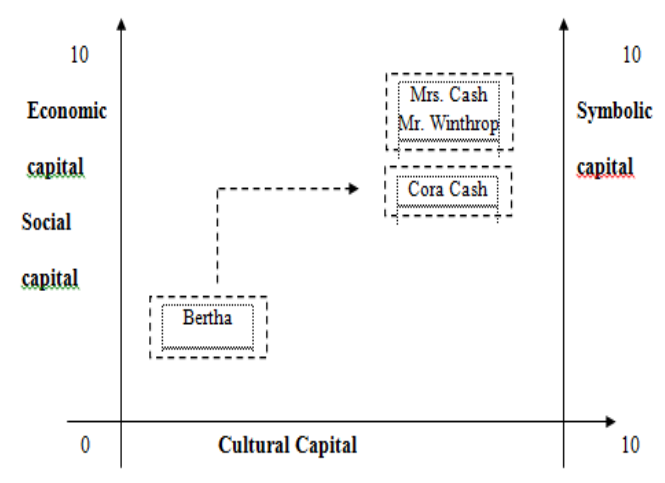

Picture 1. The social space Cora Cash in American society 
In America, Cora's family represents the high society class. Accordance to the picture above, the position of Cora is under her parents because she is the heiress that will inherit all of her parent assets certainly in economic as the only generation of Cash family. Her mother, Mrs. Cash has the higher position than Mr. Winthrop, her husband because she manages everything in their family. Her father is not subordinate; he never disputed the decision given by her mother. The position of Bertha is under Cora Cash in Newport field. She is only the special maid for Cora that always besides her anywhere Cora goes. Even though, bertha is able to enter this Newport field because she is smart. She is able to have desire for Cora Cash' performance dressing. It can be categorized as the cultural capital.

\section{The Social Space of Cora Cash in England}

To get the status as the aristocrat title, Cora Cash goes to England. She will marry to the Duke of Wareham, the ninth descendant of Wareham. He is described as a very handsome man. She goes to there as the suggestion of Mrs. Wyndham, the relation friend of her mother. The social space of Cora is different because she lives in the different culture. Besides that, she knows that if she wants to be the Duchess, she needs a strategy. She will get the new title one as Duchess which every women desire it.

In English, she meets the new English woman who has the same purpose to get the symbolic capital as the new Duchess. She is Charlotte, actually she has already married to Beauchamp but she still loves the Duke of Wareham, her boyfriend in the past. Her ambition is stronger when she knows that Cora Cash comes from America to get a title. She has aims to fail Cora's ambition. The other obstruction to get the status is Duchess Fany, the mother of Ivo or formally called the Duke of Wareham. Before the Duke of eight Wareham died, she manages everything that happens in the palace but when the prince have died she marry again as soon as she can and leave the Lulworth. (Goodwin, 2011: 81)

Lulworth is a big house like a very good place to find a husband. It is very important house and the owner must have some titles. The design of the house such European style house which is completed by eighty one housemaids that each of them have the special job to keep the house. But these English houses are traditional (Goodwin, 2011: 43).

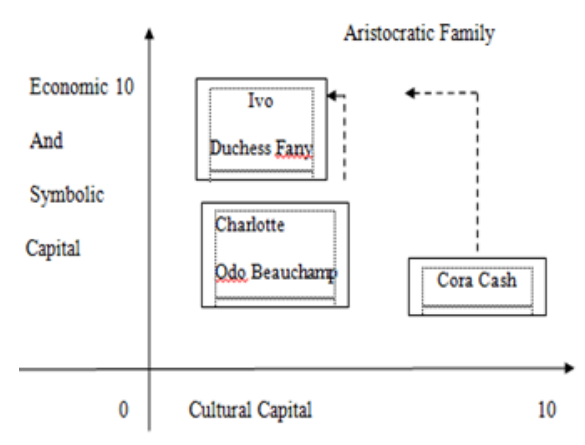

Picture 2. The social space of Cora Cash in England

In Britain Ivo's family represents the aristocratic family, the royal blood descendent of Prince of Wales, the eldest child and the heir apparent of Queen 
Elizabeth II in English. Ivo is the Ninth Duke of Wareham and now he is the Prince in the palace. The position of Duchess Fany is under Ivo because she is married and left the palace to live with her new husband. So the authority of kingdom is controlled by Ivo. Charlotte is the adopted child of Duchess Fany, she is the English. This condition is one of the accesses to get the symbolic capital as the new Duchess because the same English background culture. Charlotte is married to Odo Beauchamp Prince to fulfill her luxurious lifestyle, as the Prince who loves so much of her wife. So, he cannot refuse anything wants by Charlotte. Moreover Ivo is her boyfriend in the past that may have possibility to fall in love again. Cora as the new comer in Britain, she tries to adapt the culture and study how she makes friends in the society. In this time, the society does not know who she is. Cora wants to show her identity to get the interest from Ivo. The struggle of Cora Cash is happened in the aristocrat social class because Cora goes to England to get a title while Charlote as English. The field of the struggle especially happens in Lulworth, the palace of the Prince of Waless and his family lives.

\section{The Struggle of Cora Cash to Be the New Duchess}

According to Bourdieu (1993: 102), this struggle can be formulated as follows: $($ Habitus $\times$ Capital $)+$ Field $=$ Practice. The position of her social status is totally different when she decides to go to England to get a title; it can be seen from her social space. All of her capitals are used very well by Cora to reach the position. She tries to use her strategy to get the social status as Duchess in aristocratic field.

The main purpose of her struggle is getting the title as the part of aristocrat family. Moreover, Mrs. Cash as the best mother of Cora always wants more and wish her goes to England for one thing that cannot buy by money in the America that is a title and social status. Beside it, Cora as the only daughter wants to obey the suggestions of her mother.

So the "Duchess" which is understood by Cora is the high symbol in English society. By the symbol, she also gets the honourable title. According to Bourdieu, this symbol can be called as symbolic capital. It is the last accumulation from all of the form capital as the result of the struggle.

Firstly, Cora is going to Europe as the suggestion of Mrs. Wyndham, the lady maids and French chefs as her mother friend. She is the friendship of Prince of Wales in London. The mother helps her to get a title that is aristocrat class as the new Duchess.

"When Mrs.

Cash had heard about the royal connection, she had mad hints about introducing Cora to one of the younger princes. Mrs. Wyndham told to her if she wanted a prince she would have to go to Europe where you could find royal title by the score." (Goodwin, 2011: 223).

Secondly, she throws a party as the first greeting meet in middle of Britain society. In this way Cora wants to show her struggle in social capital. How she makes relation as the new comer in Britain.

"Cora had sent only a hundred cards for the reception but by the day of the event, she had made so many new 'friends' that the likely number of 


guests had at least
tripled. Mrs.
Wydham who had
made much her
connection with the
aristocrat class found
herself happy as
youth." (Goowin,
2011:265)

The condition above shows how Cora's struggle is getting respond. She tries to introduce to the society who she is. The way is relate to Bourdieu (1986: 244) opinions, the social capital as the connections among individuals to social network, the norms of reciprocity and trustworthiness that arise from the agent.

Another aim of the party which is held by Cora because she wants to show her passion to choose the dressing style, Cora always wears the best expensive dress as the American heiress. Her passion has the purpose to show her own dressing style it can be called distinction (Goodwin, 2011: 266)

Thirdly, Cora tries to deliver her idea that the accident happened yesterday is uncontrollable of her. As American she must ride the horse very well. Luckily, the accident felt down from the horse in a forest near the Lulworth. So, Ivo helps her and brings Cora to his house. During Cora staying at Lulworh, she tries to speak about the accident (Goodwin, 2011: 99)

Cora bridled at the implied criticism, she knew she was an excellent

horsewomen. 'I assure you, Duke, I am not in the habit of falling off my horse. What happened the other day was completely out of character. (Goodwin, 2011:99)
Based on the quotation above, Cora makes sure to Ivo that the accident happened yesterday is uncontrollable of her. Actually the conversation above is used by her to show her ability to ride the horse. It is taken from their conversation with the Duke. The American woman is very energy to ride the horse such Cora. The ability for reading horse in America society have an analogy such a woman who can control her horse it means that she can control herself. This culture is totally different from the English, only a few people can ride the horse. In the Duke family, Ivo and some Duke's valet can control the horse. In America the talent is already obtained since the teenager who is taught by the parents for their children. This talent can be categorized as the incorporated cultural form. In cultural capital, requires the agent have many talents to obtain the durable system of dispositions and represents of intellectual qualifications or human capital (Bourdieu, 1986:82).

She tells to the lady maids that she is the American heiress in 19th century. Beside it, she is the only daughter in Cash family. Being heiress she has the economic capital. Her wealth is one of the indicators that she has ability to compete with the other agents in field. It can be categorized as economic capital.

"From what I hear, she is quite the heiress. They come over to Britain on their own yacht. I do not think she is the sort of girl who would throw herself in anyone's way. My impression is that Miss Cash usually gets what she wants". (Goodwin, 2011:112)

In visiting family between Cash family and the Duchess family, they have dinner together to close each other family. 
After the dinner they take the enjoy conversation. Ivo is playing the piano slowly. Suddenly, Duchess Fany wants to know about the Cora's talent for playing piano. Cora tries to show her talent for playing the piano with the Duke.

She heard the prince saying to Ivo, 'So you have found yourself a new partner, Wareham. I remember you used to play with your mother. But I think your new Duchess is quite capable of keeping up with you." (Goodwin, 2011: 194-195)

This kind of portrayal that continuously relates to the ability of her to take the position that she wants in a field. The label of someone can be taken from another agent who admits the talent. In the society around her, Cora is admitted that she chooses to be the new Duchess because she is quite complete to Ivo's skill such as for playing the piano. Cora's skill has been obtained by learning and practicing constantly. In this novel, she does not follow the occasional course especially for playing the piano because her skills possessed by her routine practice at home.

Fourthly, She and her mother are going to London and Paris. As the heiress Cora shows her desire to choose the dressing style, it is to make the distinction (specific identity) with the other agent. The desire for her dressing can be used as the incorporated of cultural product. She tries to show her ability in the dressing style be suitable for their body (Goodwin, 2011:133)

Fifthly, During her staying in Lulworth house, Cora makes herself busies by many activities. One of her hobby is reading. Relate to that, Cora has habits for reading since she was child the parent raised her as smart as woman in future.

In the Blue
Room, Cora was
trying to concentrate
on her book. She
found most novels
hard to sympathies
with all those plain
governesses-but this
one had much
recommend it. The
heroine was
handsome, clever,
and rich, rather like
Cora herself.
(Goodwin, 2011:5)

The statement above describes how the Cora's habitus; reading habitual give influence in the cultural capital aspect. The novel which is read by her is kind of literary as the cultural product because cultural product not only limited on art products. By this activity Cora is able to complete the objectified form.

Sixthly, when Ivo birthday is coming, Cora wants to give a present for Ivo which is unforgettable thing that is a painting of her bodies self from the famous painter, Louvain. She takes this opportunity to show her ability relates to objectified cultural capital suitable with her character as American that commonly love painting. Actually Ivo is very excited about present but Ivo knows that the painting is painted by Louvain, the painter who has the bad reputations on the painting process (Goodwin, 2011: 280).

\section{The Strategy of Charlotte}

In relation to the struggling to do the contestation, Charlotte wants to fail the Cora's struggle to get symbolic capital as the new duchess. Actually Charlotte comes from poor family; her mother is died and her father is gambler. She is not a biological child of aristocrat descendent, 
but she is adopted by Duchess Fany because her father is irresponsible father (Goodwin, 2011:226)

Firstly, Charlotte married to Odo Beauchamp to fulfill her desire for anything what she wants especially to support her economic. Even she is married to the Odo Prince but Charlotte still loves Ivo so much as her ex (Goodwin, 2011: 87)

Secondly, Charlotte who lives in Lulworh wants to show her ability in dressing style especially in party which is held by Cora. She does not want if Cora's dressing is better than her as the native English. She often wears the glamour dressing. In once time, Cora admits that Charlotte is very smart for choosing the dress. The dressing which is Charlotte's must be expensive one.

"Charlotte was
smartly dressed as
ever in mauve chiffon
with black lace. Cora
turned and saw the
painting on the wall
behind her. Louvain
had painted Charlotte
wearing her riding
clothes, her hat in one
hand and her whip in
the other. Cora
realized at once why
Louvain had insisted
on painting Charlotte
as a Princess Diana."
(Goodwin, 2011:231)

From the describing above, Charlotte is very professional in fashionable level. The analogy of her perfection is like Princess Diana's beauty who wears the dress such a queen. Her desires to choose the dressing it can be called as the habitus. Because as the adoption child, Charlotte is growing up in Lulwoth, the place for the aristocratic class which the woman clothing is likes Princess Diana.
Beside it, in a dinner, she also shows up her dressing accessories. She wears the black pears earrings. The pearl is a kind of priceless jewelry that only some people who have it. In Britain the aristocrat family is the one who wears it.

Thirdly, when Ivo is playing the piano in the music room, Charlotte goes to the room. She offers him for duet playing the piano. The Duke cannot reject it because he still loves Charlotte (Goodwin, 2011: 385). This ways is her trick to get the attention for the prince or Duke of Wareham. Charlotte is very tricky woman. She does this opportunity to make interested Ivo to her. This ability can be categorized as the incorporated cultural capital form.

"May your
marriage be as happy
as mine has been."
Even then, she had
known the note to be
malign and she had
destroyed it. "I told
you Cora, I have
everything I want,
even though you
could not see your
eyes". (Goodwin,
2011:388)

Fourthly, when the Ivo's birthday is coming, she traps Cora for the suggestion gift. She shows her painting from Mr. Louvain as the famous painter in England. While Cora is does not know about the true reputation of him (Goodwin, 2011:230). The painting is used as the gift of Ivo's birthday. Unluckily Cora, Ivo is very angry to the gift. This accident makes Charlotte has the best reputation on him. Charlotte uses her cultural capital to fail the Cora's position to be the new Duchess because she knows the information about Louvain. 


\section{The Final Struggle of Cora Cash}

After Cora Cash and Charlotte are done the struggle to get the symbolic capital, they have different amount of the capital but they have the same purpose to the Duchess. Although Charlotte is married to Odo Beauchamp, she tries to fail Cora's struggle to be the new Duchess because she fond of the Duke as her past boyfriend.

Accordance to the three forms of the capitals; economic capital, cultural capital, and social capital. All of the capitals have the important role to get symbolic capital. In economic capital Cora Cash as the American heiress in 19th century, the wealth is one of the indicators that she has ability to compete with the other agents in a field. The family background gives her capital for ready to do the contestation. The dressing style and her accessories make her complete on her economic capital like Tiara.

The social capital of Cora is wider than Charlotte because Cora have the polite attitude that makes people comfortable on the conversation and have ability to speak in three languages include be French. By this ability Cora is able to make new friends in Britain. Her attitude makes everyone proud of her.

"She really is
lovely girl, so
aunaffected and
devoted to the Duke.
In New York papers
they call her an
American princess
and I must say her
manner would not be
out of place at
Windsor. Even
Duchess Fany cannot
find fault with her."
(Goodwin, 2011:
266)

In relation to the cultural capital Cora have more ability and talents than
Charlotte as the adoption child. The heiress should have education as elegantly as the queen. Another skill of Cora and Charlotte is the choosing the dressing style.

"There was a
difference, she would
tell them, between
dressing smartly and
overdressing.
American girls were,
on the whole, for
more fashionable
than their English
contemporaries, but it
did not do to rub their
noses in it."
(Goodwin, 2011:
222)

From the statement above, it shows that American dressing is better than the English. Because English still have many traditional styles while American is the modern. In the three forms of the cultural capital Cora Cash is completed very well. As the ninth of the Duke Wareham, he chooses Cora Cash, because the requirement to be her wife complete on her especially to be the new Duchess.

"Mrs.

Wyndham thought that Cora was looking suitably princess her attitude elegantly like tonight. She was wearing a pink and white striped silk dress with huge bows at the shoulders and at the waist. In her hair she wore a tiara of diamond stars and round her neck the pearls." (Goodwin, 2011:266)

The statement above portrays Cora Cash as the new Duchess. All of her 
capital is used smartly and discloses very well to do the contestation in aristocratic class. These struggling cannot be separated from the economic capital, the family background and her economic property, in social capital; she is able to make connection among her to individuals such as her relation to Mrs. Wyndham. By this meeting makes her known by society as the perfect Duchess. In cultural capital she is able to complete in three form of cultural capital. Firstly, incorporated form; Cora is able to playing the piano, choose her dressing style, speak into three languages. Secondly, objectified form; Cora show her interest on painting when Ivo's birthday coming. The painting is one the cultural product. Thirdly, Institutionalized form; as the heiress Cora has education as well as a queen, it can be measured by the economic property of her family such as school and library.

\section{The Social Space of Cora Cash as the new Duchess}

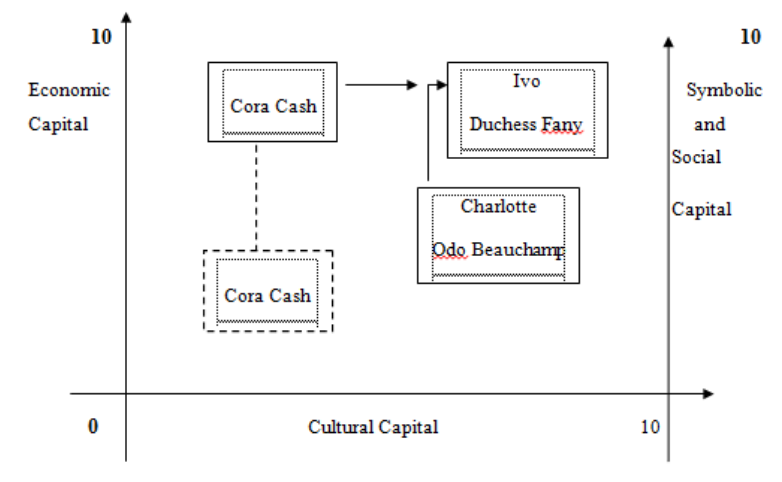

Picture 3. The social Space of Cora Cash and Charlotte in English

The struggle of Cora Cash is done by several effort and strategy. She is going to England as the suggestion of Mrs. Wyndham as her social capital. She tries to show and explore her capital to show her identity. After she shows her struggles in economic capital, cultural capital, and social capital her position higher than Charlotte. Ivo as the Duke Wareham choose her as the wife. They have married in Trinity Church Newport.

$$
\text { "So many }
$$

people shouting her name as if they knew her. Her father had shaken his head and said, it is like a royal wedding. It was exciting that all these people had some out just to see her." (Goodwin, 2011: 180)
Related to the statement above, Cora is appreciated by the American society in her wedding party such a queen. She gets the symbolic capital as the part of aristocratic family in England. She becomes the new Duchess. After she is married, she lives in Lulworth, the house that many of people want to live it. Beside it, Lulworth is symbol of honorable social class or royal blood descendent.

Finally, the movement of Cora's position is different before and after she goes to England. Her first coming to England she is the new comer who does not have any relation, her identity as the heiress is not appeared. She tries to show her strategy until she gets the symbolic capital as the wife of the Duke. The symbolic title as the Duchess makes her position increased. The position of Charlotte is same before and after doing the contestation. 


\section{CONCLUSION}

The struggle to get the symbolic capital has been done by the two characters they are Cora Cash (the protagonist character) and Charlotte (the antagonist character). They do the contestation to be the new Duchess of the Wareham in England; it can be called as symbolic struggle.The position of Cora Cash below her parents because she has a role as the daughter who lives in palace. Cora is being dominated by her mother's rules. Her position is different when she is going to England because she is new comer who will do the struggle to get the symbolic capital. The struggle of Cora Cash starts when she arrives in England. Besides that, Charlotte wants to fail the Cora's struggle to get symbolic capital as the new Duchess.

Firstly, Cora is going to England as the suggestion of Mrs. Wyndham, the lady maids and French chefs. She is the friendship of Prince of Wales in London who having relationship with her mother. The mother helps her to get a title that is aristocrat class as the new Duchess. Secondly, she throws a party as the first greeting meet in middle of Britain society. In this way Cora wants to show her struggle in social capital. How she makes relation as the new comer in Britain. Thirdly, Cora gets her accident felt down from the horse in a forest near the Lulworth. Ivo helps her and brings Cora to his house. During staying at Lulworh, Cora tries to deliver her idea that the accident happened yesterday is uncontrollable of her. As American she must ride the horse very well. Fourthly, Cora is getting well from the accident yesterday but she still staying in Lulworth. She and her mother are going to London and Paris. As the heiress Cora shows her desire to choose the dressing style, it is to make the distinction (specific identity) with the other agent.
Fifthly, During her staying in Lulworth house, Cora makes herself busies by many activities. One of her hobby is reading. Sixthly, when Ivo birthday is coming, Cora wants to give a present for Ivo which is unforgettable thing that is a painting of her bodies self from the famous painter, Louvain. Finally, the movement of Cora's position is different before and after she goes to England. The symbolic title as the new Duchess makes her position is increased. The position of Charlotte is same before and after doing the contestation.

\section{REFERENCES}

Biklen, S. K. Robert C. B. (1982). Qualitative Research for Education. USA: Allyn and Bacon

Bourdieu, Pierre. (1995). The Rule of Art: Genesis and Structure of the Literary Field. (Susan Emanuel, Trans.). California: Stanford University Press.

Boudieu, Pierre. (1986). The Form of Capital. In J.Richardson Ed, Handbook of theory and research for the sociology of education. New York : Greenwood

Bourdieu, Pierre. (1991). Language and Symbol Power. Cambridge: Polity Press

Bourdieu, Pierre. (1993). Sociology in Question. London: SAGE

Bourdieu, Pierre. (1993). The field of Cultural Production: Essay on Art and Literature. Columbia: Columbia University Press.

Devi, Rima. (2010). Perjuangan Simbolik Seorang Ilmuwan Sebagai Ayah Alternatif Pada Novel Hakase No Aishita Suushiki Karya Ogawa Yoko. Jakarta: Universitas Indonesia

Goodwin, Daisy. (2010). The American Heiress. Britain: Headline 
Publishing Group, a Hachette UK company

Harker, Richard, Cheelen Mahar dan Crhris Wilkes. (2009). Pengantar Komprehensif Kepada Pemikiran Pierre Bourdieu. Penerjemah Pipit, Meizer. Yogyakarta: Jalasutra
Sanders, Chris. (2007). Quantifying Theory: Pierre Bourdieu. Canada: York University

Thompson, John B. (2007). Editor's Introduction. Language and Symbolic Power. (9th ed.). (Gino Raymond \& Matthew Adamson, Penerjemah.). Malden \& Cambridge: Polity Press. 